\title{
Voltage-Dependent Anion-Selective Channel Protein 1
}

National Cancer Institute

\section{Source}

National Cancer Institute. Voltage-Dependent Anion-Selective Channel Protein 1. NCI

Thesaurus. Code C37292.

Voltage-dependent anion-selective channel protein 1 (283 aa, $31 \mathrm{kDa}$ ) is encoded by the human VDAC1 gene. This protein plays a role in the regulation of cell volume, the modulation of apoptosis and the permeability of the outer mitochondrial membrane. 